\title{
Physical Self-Perception, Body Posture of Nursing Students and Associated Factors
}

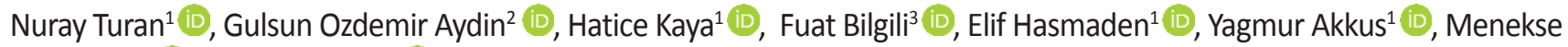 \\ Lutfiye $\operatorname{Tas}^{1}$ (iD), Meltem Tirank ${ }^{1}$ (i) \\ ${ }^{1}$ Istanbul University Cerrahpasa, Florence Nightingale Nursing Faculty, Istanbul, Turkey \\ ${ }^{2}$ Tekirdag Namik Kemal University, Health High School, Nursing Department, Tekirdag, Turkey \\ ${ }^{3}$ Istanbul University, Istanbul Medical Faculty, Department of Orthopedics and Traumatology, Istanbul, Turkey \\ Correspondence Author: Nuray Turan \\ E-mail: nkaraman@istanbul.edu.tr \\ Received: $11.05 .2017 \quad$ Accepted: 28.02.2019
}

\begin{abstract}
Objective: In this study, it was aimed to determine the relationships between physical self-perception, body posture disorders, age, gender and BMI categories and nursing students' physical self-perception and body posture disorders.

Methods: This cross sectional study was conducted. The study population was comprised of 1202 students studying at the Nursing Faculty, the sample consisted of 341 students. The data were collected by using "Structured Question Form", "Symmetrigraf", "Posture Aware by Center Road Software LLC" and "Physical Self-Description Questionnaire (PSDQ)".

Results: Students' average age was $20.33 \pm 1.60$. Body posture analysis through symmetrigraf showed that the students suffered from kyphosis, lordosis, scoliosis, flattening and curvature. Analysis of shoulder, spine, hip, wrist, neck, upper back, torso, abdomen, and back showed first-degree deformation. According to Body Posture Aware App, there was first-degree deformation on the head, the shoulder and the hip. When the scale scores of PSDQ of the students are examined; it was seen that the average score of PSDQ of female students was $265.96 \pm 40.28$ and that of male students was $294.64 \pm 42.97$.

Conclusion: The students had problems with body posture and gender played a role in posture and self-perception. Considering the period of life students go through and the fact that they will be a member of health personnel, utmost attention needs to be paid to this issue.

Keywords: Nursing students, gender, physical self-perception, body posture
\end{abstract}

\section{INTRODUCTION}

"Physical self-concept" or "physical self-perception" is of great importance in terms of getting in contact with the physical world, ability to specialize and healthy development $(1,2,3)$. This type of drive leads people to perceive their body negatively or positively $(1,4)$. Especially the university life which coincides with the period between adolescence and adulthood turn out to be a quite demanding, turbulent and painful process for the students. The fact that students discover their identities and individualize in a healthy way comes into prominence in this period $(5,6)$.

Physical self or physical perception is a fundamental component of self-confidence and self-concept. It is usual for a person who considers oneself physically sufficient or who is perceived likewise by others to like his/her own body and think that he/she will be physically sufficient on his/her own. In addition, it is also ordinary for basic structures such as self-esteem to be at high level as a result of the high level of perceived physical self-sufficiency $(7,8)$.

Ideal body-build requires both being thin and physically proper. In other words, the body needs to be proportional and healthy.
In this context, especially proper body posture turns out to be a factor that directly affects physical self-concept for both male and female students (8). American Orthopaedic Association describes posture "the state of balance in which muscles and bones can protect other body structures from injuries in upright position, sitting and lying positions $(9,10)$. In other words, posture is described as the composite of the positions of all the joints of the body at any given movement $(11,12)$. Posture is the mechanical alignment between the parts of the body. It is divided into two categories: static posture (in resting or stationary positions) and dynamic posture (in movement). Human body achieves a proper posture through the workings of muscles in coordination to ensure stability or adjust to a movement. Good posture refers to the positioning of the body in a way that balance point of each body segment is vertically situated from top to the bottom. There is an anterior convex in the neck in ideal cervical standing. Gravity falls through the earlobe in sidelong standing $(10,13-15)$.

Physical self-concept and ideal body posture might lead university students to suffer from social physical anxiety. Study findings show that girls feel social physical anxiety more than boys and they report that such anxiety is influential in their 
behaviors (2). At the same time, it is emphasized that boys have higher levels of self-esteem than girls. The number of studies on such an important and current issue is insufficient $(5,8,16)$.

\section{Aim}

In this study, it was aimed to determine the relationships between physical self-perception, body posture disorders, age, gender and BMI categories and nursing students' physical self-perception and body posture disorders.

\section{METHODS}

\subsection{Study Design}

The students in the sample group were determined through stratified random sampling (the stratum criteria are the classes the students are studying at). The samples from the targeted sub-strata were chosen by using random number tables.

\subsection{Participants}

The study population was comprised of 1202 students studying at the Istanbul University Florence Nightingale Nursing Faculty in the academic year 2015 - 2016; on the other hand, the sample consisted of 322 students, which was calculated through the formulation of sample size calculation for an existing population (95\% confidence interval, $5 \%$ margin of error, $50 \%$ frequency). To prevent any data loss, the number of the students that would be included in the sample was determined to be 341 by calculating $10 \%$ and including it to the sample. A total of 341 students, 232 female and 109 male, participated in the study. In the study using stratified sampling method, all the students whose aimed and important explanations were studied were included. 105 students are first class, 111 students are second class, 92 students are third class and 33 students are fourth class participated in the study. The criteria for participation in the study was students' voluntariness/ willingness and allowing their photos to be taken; while the criteria for exclusion from the study was having undergone a surgical operation on spine, not being voluntary or willing, and not consenting one's photos to be taken.

\subsection{Data Collection}

The data were collected by using "Structured Question Form", "Symmetrigraf", "Posture Aware by Center Road Software LLC" and "Physical Self-Description Questionnaire (PSDQ)".

Structured Question Form: The form consists of questions related to age, gender, The Body Mass Index (BMI), marital status, grade/class, family type, income statues, place of residence, substance use, chronic disease, regular medication use and doing regular exercise.

Symmetrigraf: Postural analysis was conducted through Symmetrigraf, a clear chart divided into squares. Symmetrigraf is a practical tool consisting of $10 \mathrm{~cm}$ side-squares, 9 in horizontal and 27 in vertical positions, and it enables us to spot the asymmetry in spinal cord in lateral and front plan (Figure 1). The assessment was done by stabilizing the feet at a certain spot. The person to be assessed stood behind the tool. In the posterior analysis, the mid-point between the ankles was immobilized; and in the lateral analysis, the slight tip of lateral malleolar was stabilized. The posture assessment was conducted through three scales: "normal", "1 $1^{\text {st }}$ degree deformity" and " $2^{\text {nd }}$ degree deformity". According to the points of references, deviations up to $3 \mathrm{~cm}$ was considered as $1^{\text {st }}$ degree deformity; and deviations more than $3 \mathrm{~cm}$ were referred as $2^{\text {nd }}$ degree deformity. In lateral appearance, the points of reference are slightly tip of lateral malleolar, shoulder midpoint, slightly back of hip joint, and ear tragus $(11,17)$. In postural analysis, Symmetrigraf and Bragg posture chart were used together; the person was placed on a step put behind the symmetrigraf; and the person's posture was then compared to the shapes in Bragg posture chart, and assessed as "good, moderate, and poor" $(10,11)$.

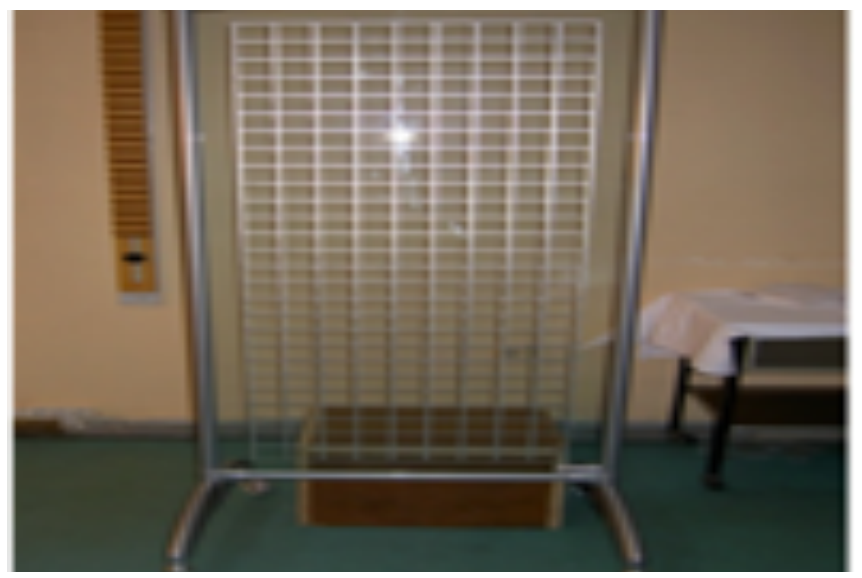

Figure 1. Symmetrigraf (11)

Posture Aware by Center Road Software LLC (App Store, United States): This application, which was developed to determine the body posture and can be downloaded to smart phones/ tablets or computers, enables people to upload their body posture photos to the app to be assessed. The app gives scores visually to the ideal postural analysis of the spots marked as red on the photos taken (18). In the study, the analysis of the visual was conducted by the researchers (Figure 2).

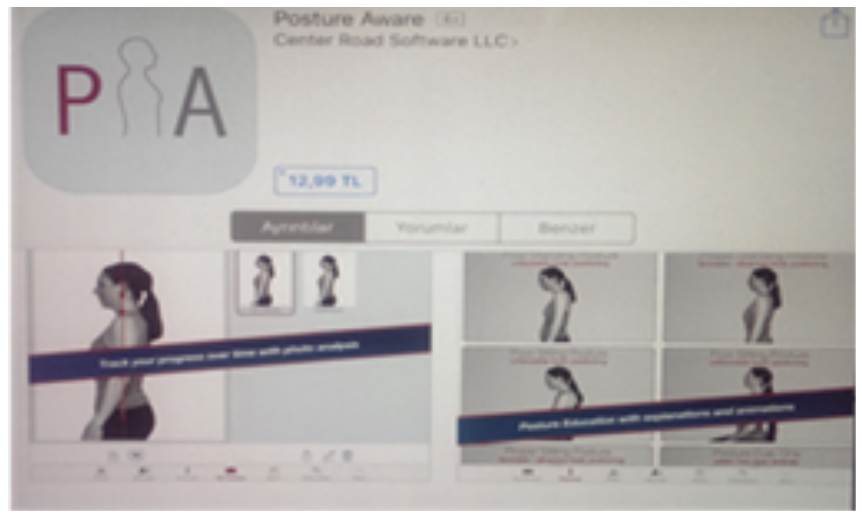

Figure 2. Body Posture Aware Application (18) 
PSDQ: The instrument was developed by Marsh, Richards, Johson, Roche and Tremayne in 1994 (19). Its Turkish reliability and validity studies were completed by Aşçı $(3,20)$. It consists of 9 subscales related to Strength, Body Fat, Physical Activity, Endurance, Sports Competence, Coordination, Health, Appearance, Flexibility as well as two global measures of Global Physical Self-concept and Global Esteem. The PSDQ is a 70-item test and it uses a 6-point likert scale with "1: Completely False" and "6: Completely True". Reverse Scoring was applied for the following subscales: Health (1.,12.,23.,45.,56.,67.), Body Fat (4.,15.,26.,37.,48.,59.), Appearance $(40 ., 62$.$) , Strengths$ (41.,31.), Flexibility and Global Esteem (22.,33.,44.,68.,70.). The scale gives scores ranging from 6 to 24 , for each dimension, in 5 different dimensions of physical perception. The high score on the scale shows a high level of physical perception in the high individual whereas the low score shows low physical perception. Internal consistency coefficient of PSDQ subscales which were adapted to Turkish ranges from Cronbach Alpha 0.87 to $0.98(3,5)$. In this study, Cronbach Alpha coefficient for PSDQ was found to be 0.893 .

\subsection{Procedures}

Students' written and oral informed consents were taken within the scope of the study. After measuring students' height and weight, "Structured Question Form" was filled in. Then, students' body posture analysis was completed by using "Symmetrigraf". Following this, students' photos were taken with the use of tablet laptops to use them in "Body Posture Aware App". After body posture analysis was completed through both methods under the guidance of an orthopedist, students were asked to fill in PSDQ, which was the final step in data collection.

\subsection{Ethical Considerations}

Ethical approval for this study was obtained from the Istanbul University Ethics Committee (16.03.2016/401). The researchers explained the purpose of the research, roles of participants, benefits and potential risks of the study, their right to withdraw at any time. Students' written consents/approvals were received with Used Confidentiality Agreement Form.

\subsection{Statistical Analysis}

For data analysis, IBM SPSS Statistics 22 (IBM SPSS, Turkey) was utilized for statistical analysis. Data were analyzed via Shapiro Wilks test and it was observed to be normally distributed. In addition to descriptive statistical methods (mean, standard deviation, frequency), Student $t$ Test was used to examine quantitative data for inter-group analysis. To analyze the data for groups of more than two, one way ANOVA test was used whereas Tukey HSH Post Hoc test was preferred to detect which group caused the difference. Chisquare test, Yates Continuity Correction and Fisher Absolute Chi-square test were used for analysis of qualitative data. Significance level was determined to be at $p<0.05$.

\section{RESULTS}

\subsection{Students' Individual Characteristics}

$68 \%$ of the participant students were female and average age was $20.34 \pm 1.69$ years. $98.8 \%$ of them were single and $32.6 \%$ were second graders. As for family, $79.2 \%$ lived in nuclear family and $33.1 \%$ had at least 4 siblings. In addition, $49.9 \%$ lived with their family. $87.7 \%$ had health insurance while $89.7 \%$ did not hold any job. 9.1\% of them suffered from a chronic disease while $9.4 \%$ were on regular medication. When it comes to habits, 9.1\% smoked and abused alcohol and $27 \%$ did not do regular exercise. BMI was found to be $22.47 \pm 3.66 \mathrm{~kg} / \mathrm{m} 2$ for the female students and $23.57 \pm 3.50$ for the male (Table 1).

Table 1. Individual Characteristics of Students $(N=341)$

\begin{tabular}{|c|c|c|c|}
\hline & & $n$ & $\%$ \\
\hline Age (years) & Avg. $\pm S D$ & $17-32$ & $20,34 \pm 1,69$ \\
\hline \multirow[t]{2}{*}{ Gender } & Girl & 232 & 68,0 \\
\hline & Boy & 109 & 32,0 \\
\hline \multirow[t]{6}{*}{ BMI Categories } & Weak & 24 & 7,0 \\
\hline & Normal weight & 240 & 70,4 \\
\hline & \begin{tabular}{|l} 
Overweight \\
\end{tabular} & 65 & 19,1 \\
\hline & 1st degree obese & 8 & 2,3 \\
\hline & 2nd degree obese & 3 & 0,9 \\
\hline & Morbid obese & 1 & 0,3 \\
\hline \multirow[t]{2}{*}{ Marital status } & Married & 4 & 1,2 \\
\hline & Single & 337 & 98,8 \\
\hline \multirow[t]{4}{*}{ Class } & 1st class & 105 & 30,8 \\
\hline & 2 nd class & 111 & 32,6 \\
\hline & 3 rd class & 92 & 27,0 \\
\hline & 4 th class & 33 & 9,7 \\
\hline \multirow[t]{2}{*}{ Family type } & Nucleus & 270 & 79,2 \\
\hline & Wide & 61 & 17,9 \\
\hline \multirow[t]{4}{*}{ Number of siblings } & Single child & 27 & 7,9 \\
\hline & 2 siblings & 133 & 39,0 \\
\hline & 3 brothers & 68 & 19,9 \\
\hline & 4 and over siblings & 113 & 33,1 \\
\hline \multirow[t]{5}{*}{ Life location } & Alone & 5 & 1,5 \\
\hline & Family & 170 & 49,9 \\
\hline & Friend & 37 & 10,9 \\
\hline & Dorm & 112 & 32,8 \\
\hline & Relative & 17 & 5,0 \\
\hline \multirow[t]{2}{*}{ Health security } & There is & 299 & 87,7 \\
\hline & No & 42 & 12,3 \\
\hline \multirow[t]{2}{*}{ Working Status } & Working & 35 & 10,3 \\
\hline & Not working & 306 & 89,7 \\
\hline \multirow[t]{2}{*}{ Chronic disease } & There is & 31 & 9,1 \\
\hline & No & 310 & 89,7 \\
\hline \multirow[t]{2}{*}{ Smoking } & Yes & 31 & 9,1 \\
\hline & No & 310 & 90,9 \\
\hline \multirow[t]{2}{*}{ Alcohol use } & Yes & 31 & 9,1 \\
\hline & No & 310 & 90,9 \\
\hline \multirow{2}{*}{$\begin{array}{l}\text { Continuous drug } \\
\text { use }\end{array}$} & Yes & 32 & 9,4 \\
\hline & No & 309 & 90,6 \\
\hline \multirow[t]{2}{*}{ Sports activity } & Yes & 92 & 27,0 \\
\hline & No & 249 & 73,0 \\
\hline
\end{tabular}

\subsection{Results of Body Posture Analysis with Respect to Symmetrigraf and Body Posture Aware App}

Posture analysis via symmetrigraf showed that $10 \%$ of the students suffered from kyphosis, $2.9 \%$ from lordosis, $1.5 \%$ from scoliosis, $19.9 \%$ from flattening, $1.2 \%$ from curvature. 
First-degree deformations were diagnosed on shoulder, spine, hip, wrist, neck, upper back, torso, abdomen, and back at the respective rates: $41.1 \%, 6.2 \%, 8.2 \%, 7 \%, 5.6 \%$, and $0.3 \%$. According to Body Posture Aware App, there was first-degree deformation on the head with $1.2 \%$, on the shoulder with $36.7 \%$ and on the hip with $2.3 \%$ (Table 3 ).

\subsection{PSDQ Scores and Comparison of PSDQ Scores with respect to Individual Characteristics}

Total average score obtained from PSDQ was 275.13 \pm 43.23 . Average score for Health subscale was $33.65 \pm 6.73$; 23.62 \pm 5.02 for Coordination, $18.72 \pm 6.40$ for Physical Activity, $26.48 \pm 6.84$ for Body Fat, $21.14 \pm 6.45$ for Sports Competence, $25.85 \pm 5.48$ for Global Physical Self-concept, $23.82 \pm 4.88$ for Appearance, 23.94 \pm 5.40 for Strength, 22.88 \pm 6.00 for Flexibility, $20.53 \pm 6.21$ for Endurance and $34.51 \pm 6.34$ for Global Esteem (Table 2).

When Table 2 is taken into consideration, it can be seen that 20-21 age group obtained statistically higher average scores of PSDQ $(p<0.05)$ in total and higher average scores from subscales of Body Fat $(p<0.05)$, Flexibility $(p<0.05)$ and Global Esteem $(p<0.05)$ compared to the students aged 19 and below (Table 3).

Male students had statistically higher scores at significant level than girls from PSDQ $(p<0.01)$, and subscales of Health $(p<0.01)$, Coordination $(p<0.01)$, Physical Activity $(p<0.01)$, Sports Competence $(p<0.01)$, Global Physical Self-concept $(p<0.01)$, Strength $(p<0.01)$, Flexibility $(p<0.01)$, Endurance $(p<0.01)$ (Table 2).

Regarding BMI measures, overweight and obese students had statistically significant higher scores than underweight and normal weight students from Strength subscale $(p<0.01)$ just like normal students' grades were higher than underweight students from Strength subscale $p<0.01$ ). Also, underweight students had statistically significant higher scores from Flexibility subscale than overweight and obese students $(p<0.05)$ (Table 2$)$.

\subsection{Comparison of Students' Individual Characteristics with Symmetrigraf and Body Posture Aware App Results}

Table 3 shows that Symmetrigraf did not indicate any statistically significant difference among the ratios of physical deformity in terms of age groups $(p>0.05)$. The rate of kyphosis $(p<0.01)$ and flattening $(p<0.05)$ among male students is statistically significantly higher than the female ones. The frequency rate of second-degree deformity on shoulder $(p<0.01)$, spine $(p<0.05)$, and the neck $(p<0.05)$ was statistically significantly higher among the male than the female. On the other hand, the rate of first-degree deformity for the female is statistically higher at a significant level than the male students $(p<0.01)$. Posture Aware App has shown that the rate of second-degree deformity on shoulder among the male is statistically significantly higher than that of the female students $(p<0.05)$.

Based on BMI categories, $25 \%$ of the underweight students, $7.5 \%$ of the ones with normal weight and $13 \%$ of the overweight and obese students were diagnosed to suffer from kyphosis. The frequency of flattening cases showed statistically significant differences $(p<0.05)$ with $33.3 \%$ for underweight students, $16.3 \%$ for normal weight students and $27.3 \%$ for the overweight and obese. Likewise, statistically significant differences were observed in cases of physical deformities on shoulder based on BMI $(p<0.01)$. $8.3 \%$ of the underweight students and $0.4 \%$ of the normal weight ones suffered from physical should deformity in the second degree.

Table 2. Student scores from subscales of Physical Self-Description Questionnaire and Physical Self-Description Questionnaire levels based on individual characteristics $(N=341)$

\begin{tabular}{|c|c|c|c|c|c|c|c|c|c|c|c|c|}
\hline \multirow{2}{*}{\multicolumn{2}{|c|}{$\begin{array}{l}\text { Physical Self-Description Questionnaire } \\
\text { Subscales }\end{array}$}} & \multicolumn{4}{|l|}{ Age Group } & \multicolumn{3}{|l|}{ Gender } & \multicolumn{4}{|l|}{ BMI Categories } \\
\hline & & \multirow{2}{*}{ 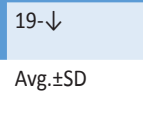 } & \multirow{2}{*}{$\begin{array}{l}20-21 \\
\text { Avg. } \pm S D\end{array}$} & \multirow{2}{*}{$\begin{array}{l}22-\uparrow \\
\text { Avg. } \pm S D\end{array}$} & \multirow[t]{2}{*}{$\mathrm{p}$} & Female & Male & \multirow[t]{2}{*}{$\mathrm{p}$} & \multirow{2}{*}{$\begin{array}{l}\text { Underweight } \\
\text { Avg. } \pm \text { SD }\end{array}$} & \multirow{2}{*}{$\begin{array}{l}\text { Normal } \\
\text { Avg. } \pm \text { SD }\end{array}$} & \multirow{2}{*}{$\begin{array}{l}\text { Overweight } \\
\text { and obese } \\
\text { Avg.tSD }\end{array}$} & \multirow[t]{2}{*}{$\mathrm{p}$} \\
\hline & $\begin{array}{l}\text { Avg.tSD } \\
\text { (Min.-Maks.) }\end{array}$ & & & & & Avg..SD & Avg. $\pm S D$ & & & & & \\
\hline Health & $33,65 \pm 6,7(39-48)$ & $32,35 \pm 6,42$ & $34,21 \pm 7,08$ & $34,25 \pm 5,98$ & 0,059 & $32,66 \pm 6,73$ & $35,77 \pm 6,24$ & $0,001^{* *}$ & $32,58 \pm 8,83$ & $33,46 \pm 6,70$ & $34,57 \pm 6,05$ & 0,328 \\
\hline Coordination & $23,62 \pm 5,02(8-36)$ & $22,78 \pm 5,18$ & $24,25 \pm 4,92$ & $23,30 \pm 4,86$ & 0,055 & $22,90 \pm 4,68$ & $25,16 \pm 5,38$ & $0,001^{* *}$ & $24,50 \pm 4,48$ & $23,87 \pm 5,03$ & $22,57 \pm 5,04$ & 0,095 \\
\hline Physical & $18,72 \pm 6,40(6-35)$ & $17,95 \pm 5,93$ & $19,41 \pm 6,75$ & $18,08 \pm 6,01$ & 0,125 & $17,86 \pm 6,29$ & $20,54 \pm 6,26$ & $0,001^{* *}$ & $16,08 \pm 6,70$ & $18,83 \pm 6,34$ & $19,19 \pm 6,38$ & 0,102 \\
\hline \multicolumn{13}{|l|}{ Activity } \\
\hline Body Fat & $26,48 \pm 6,84(6-36)$ & $25,14 \pm 6,69$ & $27,49 \pm 6,97$ & $25,91 \pm 6,37$ & $0,016^{*}$ & $26,05 \pm 6,84$ & $27,39 \pm 6,78$ & 0,093 & $34,75 \pm 3,52$ & $27,67 \pm 5,99$ & $20,18 \pm 5,16$ & $0,001^{* *}$ \\
\hline Sports & $21,14 \pm 6,45(6-36)$ & $20,02 \pm 6,61$ & $21,40 \pm 6,51$ & $22,23 \pm 5,84$ & 0,071 & $19,53 \pm 5,90$ & $24,57 \pm 6,27$ & $0,001^{* *}$ & $20,46 \pm 5,76$ & $21,13 \pm 6,20$ & $21,38 \pm 7,45$ & 0,831 \\
\hline \multicolumn{13}{|l|}{ Competence } \\
\hline Global & $25,85 \pm 5,48(9-36)$ & $25,20 \pm 5,78$ & $26,00 \pm 5,50$ & $26,52 \pm 4,88$ & 0,283 & $25,21 \pm 5,47$ & $27,22 \pm 5,27$ & $0,002^{* *}$ & $26,75 \pm 6,02$ & $26,33 \pm 5,09$ & $24,10 \pm 6,15$ & $0,006^{* *}$ \\
\hline \multicolumn{13}{|l|}{$\begin{array}{l}\text { Physical Self- } \\
\text { concept }\end{array}$} \\
\hline Appearance & $23,82 \pm 4,88(11-85)$ & $23,31 \pm 3,17$ & $23,90 \pm 3,88$ & $24,41 \pm 8,40$ & 0,348 & $23,63 \pm 3,38$ & $24,21 \pm 7,10$ & 0,306 & $26,50 \pm 12,90$ & $24,00 \pm 3,41$ & $22,42 \pm 3,91$ & $0,001^{* *}$ \\
\hline Strength & $23,94 \pm 5,40(9-36)$ & $23,33 \pm 5,58$ & $24,05 \pm 5,50$ & $24,63 \pm 4,80$ & 0,297 & $22,97 \pm 5,19$ & $25,98 \pm 5,30$ & $0,001^{* *}$ & $20,96 \pm 5,12$ & $23,75 \pm 5,21$ & $25,43 \pm 5,66$ & $0,001^{* *}$ \\
\hline Flexibility & $22,88 \pm 6,00(7-36)$ & $21,51 \pm 6,07$ & $23,62 \pm 5,82$ & $23,09 \pm 6,08$ & $0,016^{*}$ & $21,80 \pm 5,80$ & $25,18 \pm 5,79$ & $0,001^{* *}$ & $23,04 \pm 5,27$ & $23,38 \pm 5,83$ & $21,26 \pm 6,49$ & $0,025^{*}$ \\
\hline Endurance & $20,53 \pm 6,21(6-36)$ & $19,52 \pm 5,96$ & $20,81 \pm 6,25$ & $21,42 \pm 6,36$ & 0,109 & $18,86 \pm 5,69$ & $24,08 \pm 5,79$ & $0,001^{* *}$ & $19,08 \pm 6,63$ & $20,93 \pm 6,27$ & $19,74 \pm 5,82$ & 0,171 \\
\hline Global & $34,51 \pm 6,34(18-84)$ & $33,52 \pm 6,21$ & $35,40 \pm 6,61$ & $33,70 \pm 5,50$ & $0,029 *$ & $34,50 \pm 6,22$ & $34,54 \pm 6,61$ & 0,951 & $35,17 \pm 5,06$ & $34,57 \pm 6,61$ & $34,12 \pm 5,85$ & 0,751 \\
\hline \multicolumn{13}{|l|}{ Esteem } \\
\hline Total & $275,13 \pm 43,23(165-390)$ & $264,63 \pm 44,06$ & $280,55 \pm 42,89$ & $277,53 \pm 40,26$ & $0,011^{*}$ & $265,96 \pm 40,29$ & $294,64 \pm 42,97$ & $0,001^{* *}$ & $279,88 \pm 43,72$ & $277,92 \pm 42,52$ & $264,96 \pm 44,26$ & 0,062 \\
\hline \multicolumn{13}{|c|}{$\begin{array}{l}\text { Min: Minimum,; Max: Maximum, Avg.: Average; SD: Standart Deviation } \\
\text { One Way ANOVA, Student t Test } \quad{ }^{*} p<0,05^{* *} p<0,01\end{array}$} \\
\hline
\end{tabular}


Table 3. State of physical deformity and analysis of physical deformities in terms of individual characteristics based on Symmetrigraf and Body Posture Aware App Results ( $N=341)$

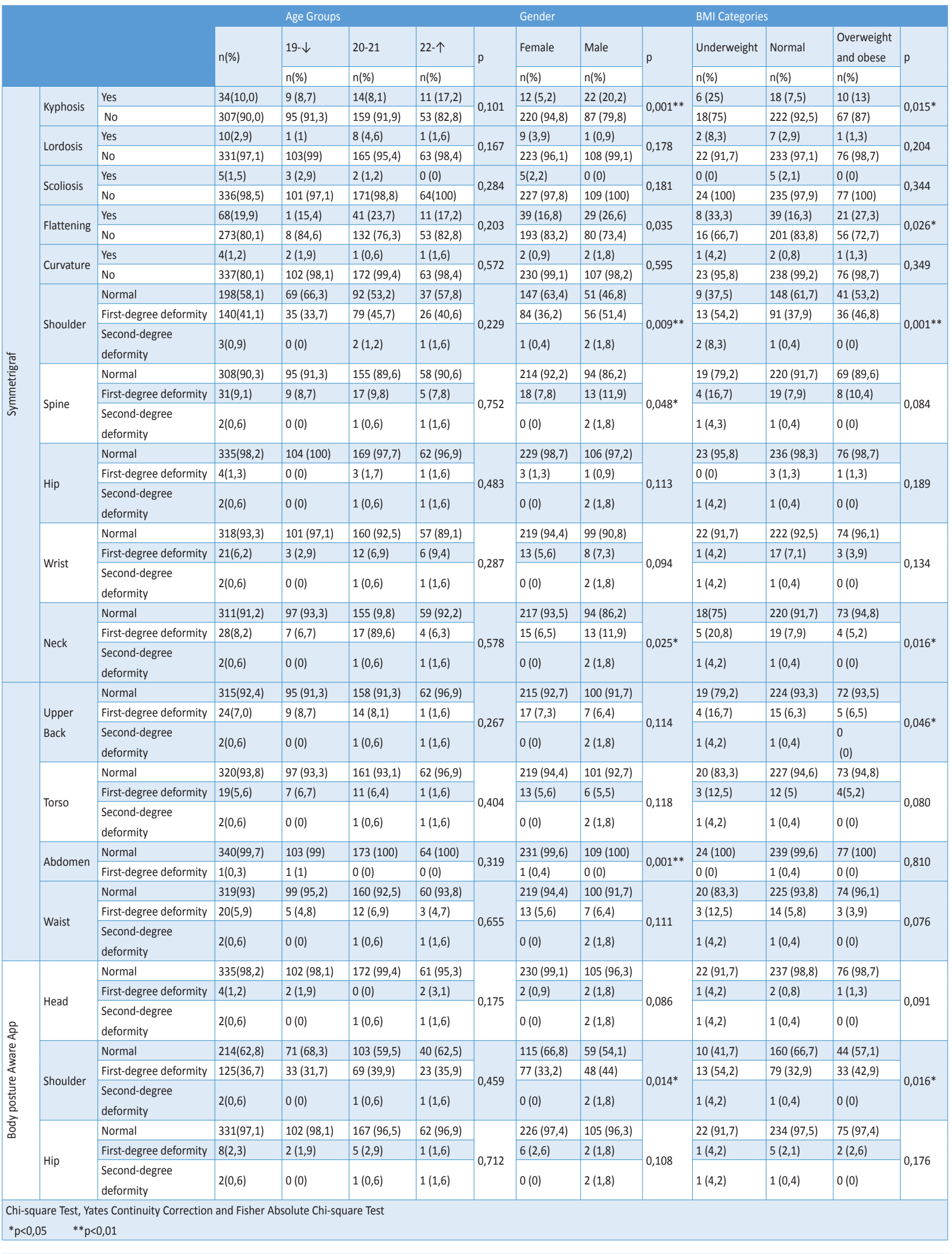


In the same manner, there were statistically significant differences in physical neck deformity cases $(p<0.05)$ in the second degree at the rates of $4.2 \%$ among underweight ones and $0.4 \%$ among the normal weight students (Table 3 ).

Based on Body Posture Aware App results, statistically significant differences were observed among BMI categories in the rates regarding physical deformity $(p<0.05)$. That is, $4.2 \%$ of the underweight participants and $0.4 \%$ of the students with normal weight suffered from neck deformity in the second degree (Table 3).

\section{DISCUSSION}

Symmetrigraf assessments showed that kyphosis in $10 \%$ of the students, lordosis in $2,9 \%$, scoliosis in $1,5 \%$, flattening in $19,9 \%$ and curvature in $1,2 \%$ were identified while there was first-degree deformity in shoulder, spine, hip, wrist, upper back, torso, abdomen and back parts. Similarly, body posture analysis of Body Posture Aware App revealed first-degree deformities in the head, shoulder and hip. The fact that body posture analysis through Symmetrigraf and Posture Aware App showed similar physical deformities indicates that both methods are reliable. In today's world, university students, called Generation Y, often use technological tools related to the Internet in their daily lives, which might reach addiction levels. Today, problems in body posture have occurred in addition to the obesity problem that has increased in ratio due to reduction in physical activities and increasing use of technological tools, which is one of the findings of this study that was expected in relation to students' technology use (21-24).

20-21 year-old students' total scores of PSDQ and average scores of the subscales Body Fat, Flexibility, and Global Esteem were found to be higher than those of the group aged 19 year old and below. This finding can be attributed to the fact that students who are training to be nurses are professionally more conscious and have increased their accumulation of knowledge thanks to the courses they take in the university and accordingly have made changes in their lives.

Male students' total scores of PSDQ and average scores of the subscales Health, Coordination, Physical Activity, Sports Competence, General Physical Self-Concept, Strength, Flexibility and Endurance were found to be higher than the scores female students obtained. This finding demonstrates that female students consider themselves less able compared to male students when it comes to physical selfperception levels in terms of health, coordination, physical activity, sports competence, general physical self-soncept, strength, flexibility and endurance. The finding along these lines is attributable to the fact that male students perceive themselves to be better in the fields mentioned above and that they consider themselves privileged in such areas because of gender. Previous studies show that the male participants obtain higher scores than the female $(5,25-28)$.
According to BMI measures, students who are overweight and obese scored higher on average in Strength subscale than underweight and normal weight students. Also, normal weight students scored significantly higher in Strength subscale compared to underweight students. However, underweight students' average scores of Flexibility subscale were significantly higher than overweight and obese students. Currently, standards for being physical attractive are increasing more and more. The female pay attention to thinness and flexibility whereas the male care about muscular and strong body build and cultures impose standards for physical attractiveness, body weight and body build $(2,29,30)$. This finding of the study can be assumed as the reflection of existing perceptions of the society on students.

Based on Symmetrigraf assessment, the rate of kyphosis and flattening as well as second-degree deformities in the shoulder, spine and neck is higher among the male than the female. On the other hand, the rate of first-degree neck deformity among the female is higher than the male counterparts. Body Posture Aware App shows that seconddegree shoulder deformity was identified in male students more often than female students. There might be various causes of posture-related problems. Among the primary ones come the following: having experienced an accident or trauma, weakness in lower back, abdomen and upper back muscles, sitting position, posture and movements incompatible with body mechanics, carrying heavy stuff, non-ergonomic desks, carelessness about body posture starting from adolescence, girls' desire to hide physical changes in their body or sitting slanted due to having big breasts, computer use for long periods and placing computer not on the head level $(13,31,32)$. The finding of the study can be explained with the fact that female or male students do not pay attention to the practices mentioned above.

Symmetrigraf measurements show that underweight, normal weight, overweight and obese students suffer from flattening whereas underweight students and the ones with normal weight suffer from second degree shoulder and neck deformities. According to Posture Aware App, underweight and normal weight students suffer a seconddegree abnormality in shoulder. According to Body Mass Index, similar problems were diagnosed through both methods. The BMI is the value of the body mass divided by the square of the body height, and is universally expressed in units of $\mathrm{kg} / \mathrm{m} 2$. It is used to predict body weight based on height. Assessment was conducted in line with BMI intersecting values suggested by World Health Organization (33). If $\mathrm{BMI}$ is 25 and over, the risk of hypertension (HT), type 2 Diabetes Mellitus (DM) and cardiovascular disease increases depending on obesity level. Therefore, assessment of university students' BMI is quite crucial in terms diagnosing future problems related to Internet and technological tool use. Similarly, the study conducted by Briggs et al. (34) reveals that the body parts where the most severe pain is felt are the neck and shoulder areas among children and adolescents who use computers. 
These findings are believed to result from limitations in physical activities and changes in dietary habits because of increasing use of technology.

It was observed that average scores that students obtained from PSDQ were at intermediate level, they encounter problems related to body posture and gender is influential in posture and self-perception. In the light of the findings, it is recommended that;

- Physical activities be planned and a conducive environment be provided so that students can develop their physical self-perception and minimize the deformation of body posture.

- Courses that can boost physical self-perception be integrated into the curriculum.

Conflict of Interest: No conflict of interest was declared by the authors.

Financial Disclosure: The author's declare that they have no conflict of interest. There are no other potential conflicts of interest pertaining to this work.

\section{REFERENCES}

[1] Yaman C, Tesneli O, Kosu S, Yalvarici N, Tel M, Gelen N. Elit seviyedeki değişik spor branşlarının fiziksel benlik algısı üzerine etkisi. IBD 2008; 5: 1-17.

[2] Bastug G, Akandere M, Yildiz H. Sedanter genç bayanlarda aerobik egzersizn vücut kompozisyonu ve kendini fiziksel tanımlama değerlerine etkisi. SPD 2011; 2(2): 22-27.

[3] Asci FH. The reliability and validity of PSDQ for Turkish population. In: Congress Proceedings of Vth Sport Sciences Congress, Hacettepe University, Turkey: Ankara; 3-5 November, 2000; 122-123.

[4] Bassett-Gunter R, McEwan D, Kamarhie A. Physical activity and body image among men and boys:A meta-analysis. Body Image 2017; 22(2): 114-128.

[5] Asci FH. Fiziksel benlik algısının cinsiyete ve fiziksel aktivite duzeylerine gore karsilastirilmasi. SBD 2004; 15: 39-48.

[6] Fox K, Corbin C. The physical self-perception profile: Development and preliminary validation. Int. J. Sport Exerc. Psychol. 1989; 11: 408-430.

[7] Cetinkalp CO. Optimal performans duygu durumu ve fiziksel benlik algısı: Dansçılar üzerine bir çalışma. Ege Üniversitesi Türk Halk Oyunları Anabilim Dalı, Yüksek Lisans Tezi, 2011.

[8] Hayes SD, Crocer PR, Kowalski KC. Gender differences in physical self perceptions, global self-esteem and physical selfperception profile model. J. Sport Behav. 1999; 22, 1-4.

[9] Howorth B. Dynamic posture. JAMA, 1946; 131(17): 1398-404.

[10] Basari GO, Balci P, Nohutlu E, Ulusoy S, Vayvay ES, Sertoglu, E. Baltaci G. Fizyoterapi öğrencilerinde bilincin postür üzerine etkisi. J Sports Sci 2009; 11: 31-37.

[11] Ecerkale, O. Postür analizinde symmetrigraf ile orthoröntgenogram sonuçlarının değerlendirilmesi Sağıık Bakanlığı Okmeydanı Eğitim ve Araştırma Hastanesi Fizik Tedavi ve Rehabilitasyon Kliniği, Yüksek Lisans Tezi, İstanbul, 2006.
[12] Simsek D, Ertan, H. Postural kontrol ve spor: Spor branşlarına yönelik postural sensör-motor stratejiler ve postural salınım. Spormetre Beden Eğitimi ve Spor Bilimleri Dergisi 2011; IX: 8190.

[13] Kaya N, Turan N. Hareket ve Egzersiz. T. Atabek Asti, A. Karadag. Hemşirelik Esasları Hemşirelik Bilimi ve Sanatı içinde. İstanbul: Akademi Basın ve Yayıncılık Ltd.Şti; 2013.

[14] Gunduz, H. Yaşılıarda postür ve yürüme. Turk J. Geriatr. 2003; 155-162.

[15] Asti T, Kaya H, Turan N, Guven NO, Culha Y. The effect on the healthy lifestyle behaviours of e-health literacy in nursing students. In: 2nd World Conference on Technology, Innovation and Entrepreneurship Congress Book, 12-14 May, Turkey: Istanbul. 2017, pp.25.

[16] Biddle S, Page A, Ashford B, Jennings D, Brooke R, Fox F. Assesment of children's physical self-perception. Int J Adolesc Youth. 1993; 4: 93-109.

[17] Kaya Y. Sportif hareketlerin postür üzerine etkileri. Selçuk Üniversitesi Sağlık Bilimleri Enstitüsü, Yüksek Lisans Tezi, Konya, 1991.

[18] App Store. Applications. Available from: URL: https://itunes. apple.com

[19] Marsh HW, Hey J, Roche LA, Perry C. Structure of physical selfconcept: Elite athletes and physical education students. J. Educ. Psychol.1997; 89(2): 369-380.

[20] Asci FH. Self-perception and exercise. Hacettepe J. Sport Sci. 2004; 15(4): 233-266.

[21] Kaya H, Turan N, Hasoglu O, Gure O, Arslanova E, Elmas G. Hemşirelik fakültesi öğrencilerinin sosyal ağ sitelerini kullanma amacı ile iletişim becerileri arasındaki ilişkinin incelenmesi. Iletişim Kuram ve Araştırma Dergisi 2015; 40: 17-31.

[22] Kaya N, Turan N, Kamberova HA, Cenal Y, Kahraman A, Evren M. Hemşirelik öğrencilerinin sanat özelliklerine göre iletişim becerileri ve sosyal zekâ düzeyleri. HEAD 2016; 13: 282-290.

[23] Turan NK, Acaroglu R. The relationship between the anxiety levels of adolescents who undergo surgical interventions and their parents and analysis of anxiety causes. J Med Sci 2012; 32(2): 308-315.

[24] Ozdemir G, Kaya H. Midwifery and nursing students' communication skills and life orientation: Correlation with stress coping approaches. Nurs Midwifery Stud.2013; 1: 1-12.

[25] Gilson, ND, Cooke CB, Mahoney CA. Adolescent physical selfperceptions, sport/exercise and lifestyle physical activity. Health Education 2005; 105(6): 437-450.

[26] Lindwall M. Hassmén P. The role of exercise and gender for physical self-perceptions and importance rating in Swedish university students. Scand J. Med. Sci. Sports 2004; 14: 373380.

[27] Schmalz DL, Davison KK. Differences in physical self-concept among pre-adolescents who participate in gender-typed and cross-gendered sports. J. Sport Behav. 2006; 29(4): 335.

[28] Pehlivan Z. Beden eğitimi öğretmenlerinin fiziksel olarak kendilerini tanımlamaları, 5. Ulusal Beden Eğitimi ve Spor Öğretmenliği Sempozyumu Bildiriler Kitabı. 2-3 Kasım Adana: 2007, 59-64.

[29] Gill DL, Williams L. Psychological dynamics of sport and exercise (3rd ed.). IL: Human Kinetics, Champaign, 2008: p.26.

[30] Tiggemann M. Body image across the adult life span: Stability and change. Body Image 2004; 1: 29-41. 
[31] Sonstroem. RJ. Physical self-concept: assessment and external validity. Exerc. Sport Sci. Rev. 1998; 26: 133-164.

[32] Whelan A, Haywood P, Galloway S. Low self-esteem: Group cognitive behaviour therapy. British J.Learn. Disabil. 2007; 35(2): 125-130.
[33] World Health Organization (2010). Global database on body mass index. Available from: URL: www.apps.who.int/bmi/ index.jsp?introPage=intro_3.html.

[34] Briggs A, Straker L, Greig A. Upper quadrant postural changes of school children in response to interaction with different information technologies. Ergonomics, 2004; 24(7): 790-819.

How to cite this article: Turan N., Aydin G. O., Kaya H., Bilgili F., Hasmaden E., Akkus Y., Lutfiye T. M., Tirank M. Physical Self Perception, Body Posture of Nursing Students and Associated Factors. Clin Exp Health Sci 2019; DOI: 10.33808/marusbed.546817 